\title{
Temporal and spatial resource use by female three-toed sloths and their young in an agricultural landscape in Costa Rica
}

\author{
Oscar Ramirez ${ }^{* 1,2,3}$, Christopher Vaughan ${ }^{2,3,4,5}$, Geovanny Herrera ${ }^{2} \&$ Raymond Guries $^{4}$ \\ 1. School of Biological Sciences, Universidad Nacional, Heredia, Costa Rica; osoramirez@gmail.com \\ 2. Milwaukee Public Museum, Milwaukee, WI 53233-1478; cvaughan@acm.edu,wesgeova@yahoo.com \\ 3. International Institute for Wildlife Conservation and Management, Universidad Nacional, Heredia, Costa Rica. \\ 4. Department of Forest and Wildlife Ecology, University of Wisconsin, Madison, WI 53706; rpguries@wisc.edu \\ 5. Associated Colleges of the Midwest, San Jose, Costa Rica. \\ * Corresponding author
}

Received 26-VIII-2010. C Corrected 09-II-2011. Accepted 10-III-2011.

\begin{abstract}
The information on ecological behavior of wild sloths is very scarce. In this study we determined the home ranges and resources used by three adult female three-toed sloths (Bradypus variegatus) and their four young in an agricultural matrix of cacao (Theobroma cacao), pasture, riparian forests and living fencerows in Costa Rica. Births occurred during November-December and the young became independent at five to seven months of age. Initially, mothers remained fixed in one or a few trees, but expanded their use of resources as young sloths became independent from them. Mothers initially guided the young to preferred food and cover resources, but they gradually left their young in small nucleus areas and colonized new areas for themselves. Home range sizes for young sloths (up to seven months of age) varied between 0.04-0.6 hectares, while home range sizes for mothers varied from 0.04-25.0 hectares. During the maternal care period, 22 tree species were used, with the most common being Cecropia obtusifolia (30.9\%), Coussapoa villosa (25.6\%), Nectandra salicifolia (12.1\%), Pterocarpus officinalis (5.8\%) and Samanea saman (5.4\%). However, young sloths used only 20 tree species, with the most common being C. villosa (18.4\%), S. saman $(18.5 \%)$ and N. salicifolia $(16.7 \%)$. The cacao agroforest was used only by mother sloths and never by their young following separation. However, in the riparian forest, both mother sloths and young used the tree species. A total of 28 tree species were used by the mother sloth; including the food species: C. obtusifolia, C. villosa, $N$. salicifolia and P. officinalis. However, the young used 18 trees species in this habitat with $N$. salicifolia and S. saman most commonly used, although they rested and fed during the day in $C$. obtusifolia, $C$. villosa and $O$. sinnuata. The cacao agroforest with adjacent riparian forests and fencerows provides an important habitat type that links the smaller secondary forests and other patches. Rev. Biol. Trop. 59 (4): 1743-1755. Epub 2011 December 01.
\end{abstract}

Key words: B. variegatus, spatial distribution, home range, maternal care, resource use, cacao agroforest, agricultural landscape.

Little information exists on the behavioral ecology of wild sloths because they are solitary, nocturnal, cryptic and thus difficult to observe (Soares \& Carneiro 2002). Studies on wild sloths have focused on determination of sex ratios (Meritt \& Meritt 1976), agonistic behavior (Greene 1989), translocation experiments (Chiarello 2004), sloth habitat selection (Montgomery \& Sunquist 1978), adult sloth home ranges (Sunquist \& Montgomery 1973) and vocalizations (Montgomery \& Sunquist 1974). The three toed sloth is considered a species of special concern (Chiarello 2008) and is listed in Appendix II o CITES (CITES, 2010). Sunquist \& Montgomery (1973) described $B$. variegatus as more active diurnally then nocturnally, similar to other species of Bradypus (Chiarello 1998).

Parental or maternal care is often defined as behavior that may increase fitness of parent's 
offspring (Clutton-Brock 1991). The age at which young mammals leave their mothers is well-established for some primate species, such as macaques (Macaca spp.) and baboons (Papio spp.; DeVore's 1963, Rowell et al. 1968, Altmann 1978). However, observations of wild sloth maternal behavior are rare (Soares \& Carneiro 2002). Captive studies have revealed that three-toed sloths are dependent on mothers at birth, but became independent after about six months (Britton 1941, Montgomery \& Sunquist 1978, Eisenberg \& Maliniak 1985). Two-toed sloth (Choloepus hoffmanni) young become independent of their mothers between nine to twelve months of age in captivity (Veselovsky 1966, Meritt 1985, Partridge 1991). In the wild, sloth mothers have been observed to leave their young and colonize new areas (Montgomery \& Sunquist 1978, Taube et al. 2001), but the temporal and spatial patterns leading to separation are not well understood. The objective of the present study was to examine temporal and spatial patterns of resource use by three-toed sloth mothers and their young from birth to separation.

\section{MATERIALS AND METHODS}

Study site: The study was carried out near the village of Pueblo Nuevo de Villa Franca, Limon Province $\left(10^{\circ} 20^{\prime \prime} \mathrm{N}-83^{\circ} 20^{\prime}\right.$ W) located $85 \mathrm{~km}$ Northeast of the capital city of San José. This region is in the Premontane Wet Forest life zone (Holdridge 1978) at approximately $100 \mathrm{~m}$ elevation. The study centered on a riparian forest fragment at the periphery of a 120 ha cacao agroforest that was adjacent to secondary forest and living fence rows. These areas with trees were inhabited by sloths and embedded in a larger agricultural matrix dominated by banana and pineapple monocultures and cattle pasture (Fig. 1). The cacao agroforest is bisected by several streams and water channels, some of which contain vegetation that functions as a biological corridor. The cacao agroforest, secondary and riparian forest and living fencerows all contain trees at varying densities that provide resources for sloths that are less available under other land uses. The regular arrangement, low height and open understory of the

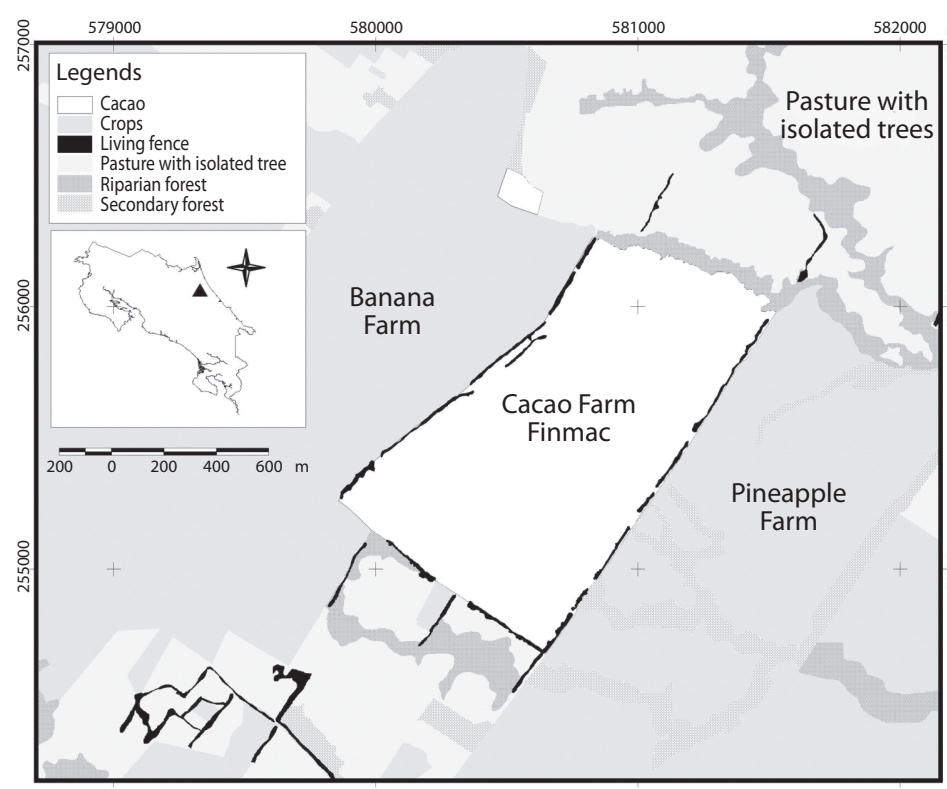

Fig. 1. Study area and capture site of the young Bradypus variegatus, Pueblo Nuevo de Guacimo, Limón. Costa Rica. 
cacao trees greatly facilitated sloth observation in adjacent riparian strips.

Capture and radio-telemetry: Between January and February, 2004, three-toed sloths were caught in the cacao agroforest or adjacent living fence rows. Animals were carried in a burlap sack to a processing site where they were sexed, weighed, measured and where a pit tag (Trovan, Electronic Identification System, ID-100US) was inserted sub-dermally between the shoulder blades. A radio collar (Mod-210; Telonics-Electronics Consultants, 932 E. Impala Avenue, Mesa, Arizona 85204-6699) was placed around each sloth's neck and they were released at their capture site. Mothers were located by radio telemetry using a Yagi (RA2AHS) antenna and Telonics TR-4 receiver. From direct observations, three of four young were born during November and December (2004); the fourth young sloth had been born in November 2003 (Table 1). Between January/ December-May (2005), radio telemetry data was collected from the mothers' radios because the young were always attached to her. In May of 2005, radio collars were placed on the four young three-toed sloths because all except one showed signs of separating from their mothers (Table 1). Data were collected on the tree species and location and resource use by the mother sloths at three or four day intervals during 12 to 14 months (November 2004 -December 2005); similar data were collected on the young sloths at three or four day intervals for six to eight months (May-December, 2005) following separation from their mothers (Table 1). Exact positions of mothers and young were determined using a GPS Magellan Sport Track held directly beneath each individual while they rested or foraged in trees.

Analysis of home ranges: Home range estimates for each sloth were constructed using a minimum convex polygon that employed $100 \%$ of recorded observations (Mohr 1947). We used the program Arc View 3.3 (Environmental Systems Research Institute, Inc., Redlands, California) and the extension "animal movement" and "home range" to calculate home ranges for each individual. Home ranges of mothers and young were estimated for two periods: a) nurturing period (November to April) and b) separation period (May to December). A Kernell analysis (using Arc View input) was used to establish nucleus areas (White \& Garrot 1990) for both young and their mothers for both periods.

Analysis of habitat used: Habitat types were delineated using an image obtained from the National Program for Research in Airtransport and Remote Sensing and geo-referencing Lambert north with a geographic information system (GIS). To evaluate resource use, all relocations were plotted on a map depicting the various vegetation types. Six habitat types were defined: a) riparian forest and vegetation formations along water courses, b) cacao agroforests, c) pasture with isolated trees, d) monoculture crops, e) living fencerows and f) secondary forest. A simple Chi square goodness of fit test was used to evaluate whether sloths exhibited preferences for certain habitats during the nurturing and separation periods

TABLE 1

Identification of female Bradypus variegatus and young with their tracking period duration

\begin{tabular}{cccccc} 
Young RC & Birth date & Mother RC* & Points used & Tracking period of young & Month of separation \\
70 & 3-Nov-03 & 24 & 26 & May-Oct 2005 & Mar-04 \\
78 & 10-Nov-04 & 143 & 28 & May-Dec 2005 & May-05 \\
82 & 10-Dec-04 & 282 & 17 & May-Ago 2005 & Apr-05 \\
84 & 10-Nov-04 & 24 & 40 & May-Dec 2005 & May-05 \\
\hline
\end{tabular}

$*$ RC=Radio collar 
and if the use of tree was different by mothers during the maternal care or post-maternal care periods (Zar 1984). Habitat use was compared between the mothers and their young for the nurturing and separation periods using a MannWhitney U test.

A non-parametric statistic (Kruskal-Wallis test) was used to compare the home range estimates for mothers and offspring during the nurturing and separation periods (95\% confidence intervals). Chi-square statistics (Zar 1984) were used for comparing preferences for cover trees and periods of use during maternal care, post-maternal care toward young, or for mothers following separation.

\section{RESULTS}

From mid-January to December 2004, a total of 464 GPS locations were collected for the mother sloths and their young (353 for mothers, 111 for young; Table 1). During the nurturing period (November to April), the mothers carried the young everywhere. The offspring became more independent between five and seven months of age when mothers left the young and established themselves in new areas nearby.

Spatial distribution: Home ranges for young were variable after separation, but smaller than for their mothers (0.04-0.6ha, $\bar{\chi}=0.3$ ha $\pm 0.1 \mathrm{SD}$; Table 2). Young sloth home ranges were confined to nucleus areas originally occupied with the mothers (Fig. 2a, 2b, 2c). Adult female home ranges with offspring also varied (0.04-18.9ha, $\bar{\chi}=7.1 \mathrm{ha} \pm 5.9 \mathrm{SD})$ and increased after separation from the offspring, but showed no significant differences between nurturing and separation periods (KruskalWallis, $\mathrm{H}=4.5$, d. $\mathrm{f}=1.5$, $\mathrm{p}=0.03)(3.0-25.0 \mathrm{ha}$, $\bar{\chi}=12.1$ ha $\pm 6.6 \mathrm{SD}$ ) (Table 2). Mother sloths lived in two (Fig. 2b, 2c) or three (Fig. 3a) nucleus areas during the study period. Only one nucleus was used by the young after separation from their mothers (Fig. 2a, 2c).

Habitat use: Only four habitat types were used by the mothers and young (riparian forests, pasture with isolated trees, living fence and cacao agroforests). The monoculture crop areas and secondary forests were not used during this study. Riparian forest was the most heavily utilized habitat before and after separation for both mothers and young with 373 GPS relocations, cacao agroforest was second (149 relocations), pasture with isolated trees third (118 relocations) while living fencerows had only a single relocation. This marked preference for specific habitats was highly significant $\left(\chi^{2}=999.45\right.$, d.f $\left.=5, \mathrm{p}<0.01\right)$.

Habitat use (proportional area in ha) was compared between the mothers and their young for the nurturing and separation periods but

TABLE 2

Home range estimates for Bradypus variegatus mothers and their young

\begin{tabular}{cccc} 
RC* & Ha & Perimeter & Period \\
RC14_c and RC78 & 0.44 & 260.36 & With young \\
RC14_c & 8.31 & 2017.20 & After separation \\
RC24 and RC84 & 18.86 & 1976.22 & With young \\
RC24 & 24.98 & 2219.87 & After separation \\
RC28 ${ }^{2}$ and RC82 & 1.95 & 706.23 & With young \\
RC28 2 & 2.98 & 983.49 & After separation \\
RC70 & 0.56 & 576.86 & After separation \\
RC78 & 0.24 & 205.73 & After separation \\
RC82 & 0.04 & 80.37 & After separation \\
RC84 & 0.23 & 219.25 & After separation \\
\hline
\end{tabular}

\footnotetext{
$* \mathrm{RC}=$ Radio collar
} 

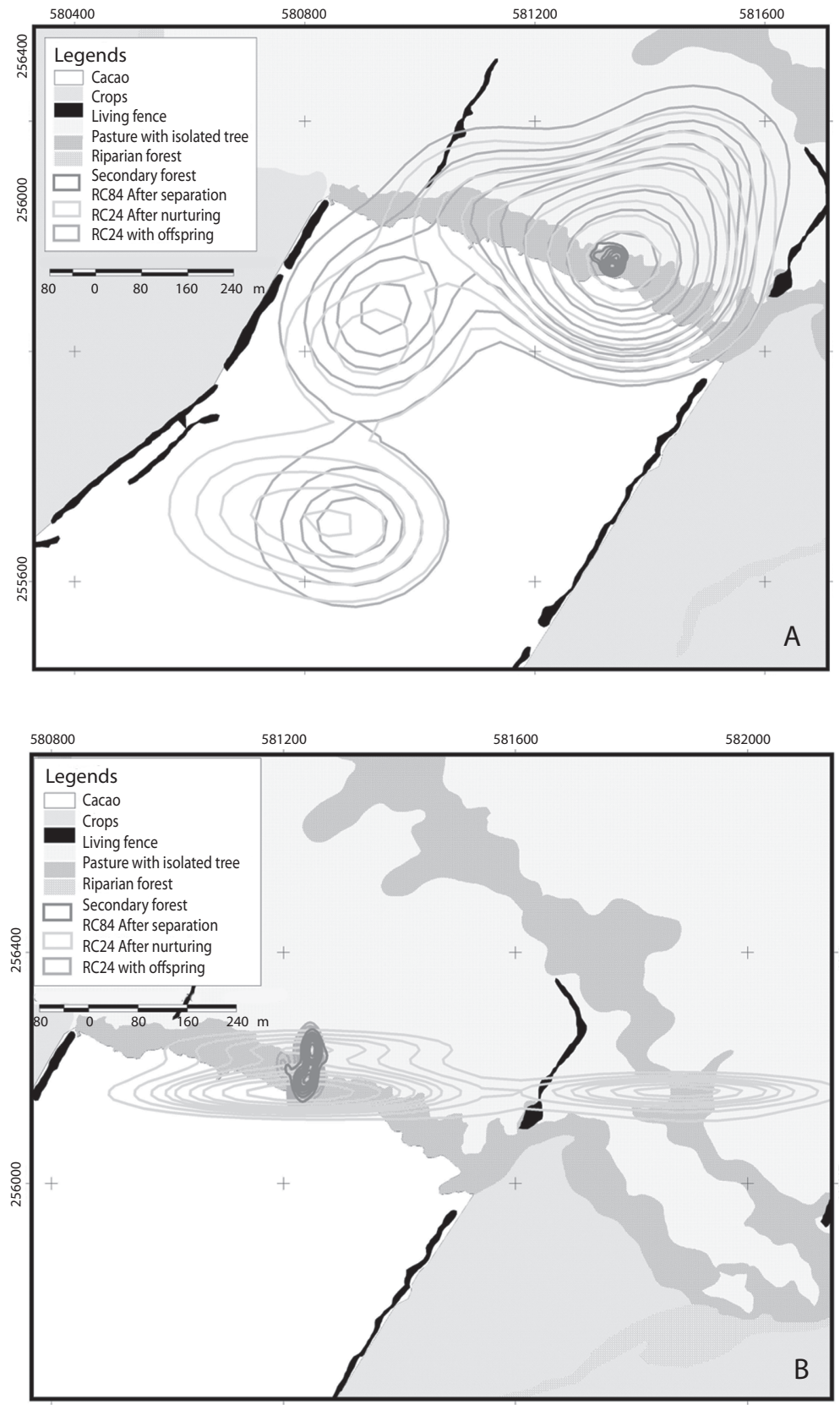

Fig. 2. Home range of young and their mothers using Kernell Polygons to show periods mother-young and post motheryoung for Bradypus variegatus. a) RC84 and mother RC24; b) RC78 and mother RC14. 


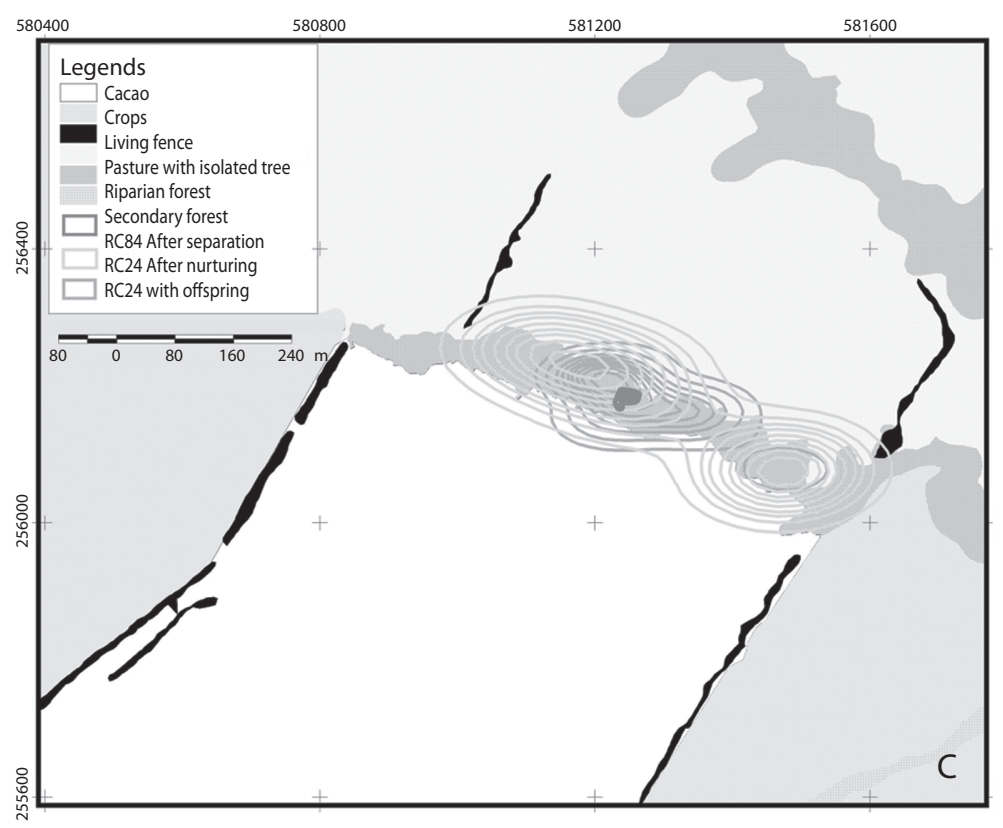

Fig. 2. Home range of young and their mothers using Kernell Polygons to show periods mother-young and post motheryoung for Bradypus variegatus. c) RC28 and mother RC82.

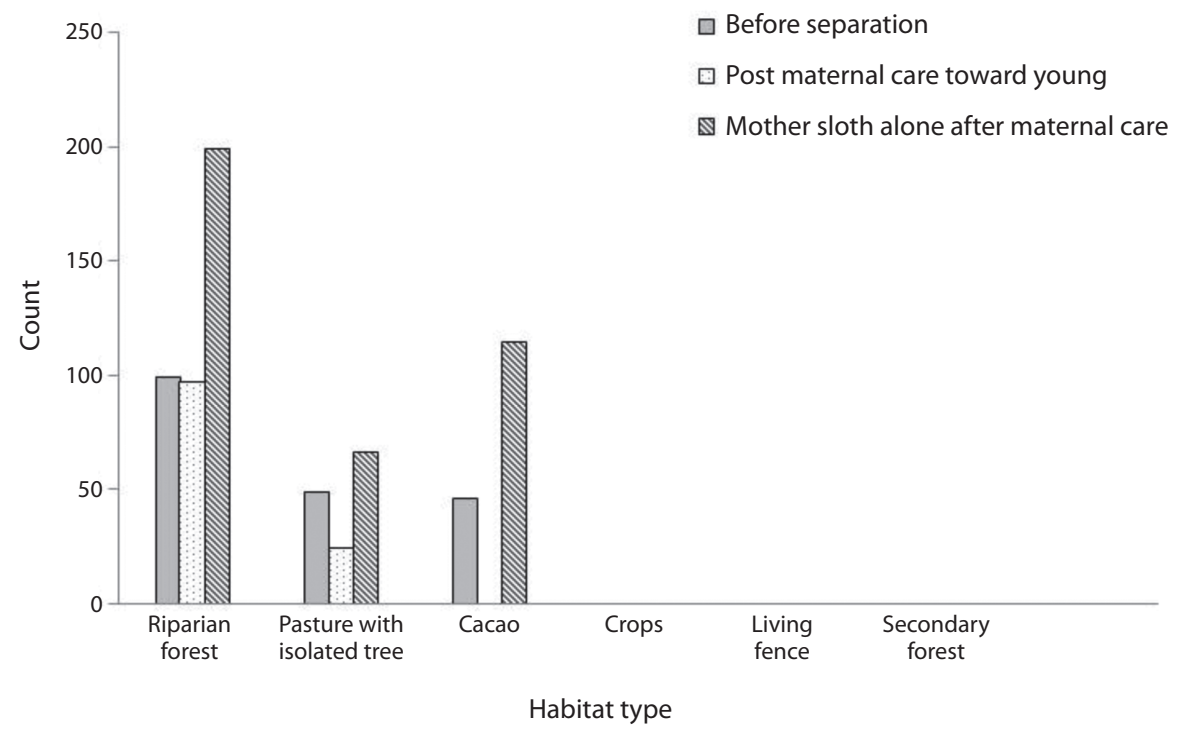

Fig. 3. Habitat used of Bradypus variegatus young and their mothers, by periods. 
no significant difference was found (MannWhitney test: $\mathrm{U}=-4, \mathrm{p}=0.53$ ). No differences in habitat use before and after separation were observed for mother sloths $(\mathrm{U}=5, \mathrm{p}=0.45)$, nor between the post maternal care versus the mother sloth alone after maternal care $(\mathrm{U}=7$, $\mathrm{p}=0.26$ ). The cacao agroforest and riparian forest were important habitats for mothers before separation (43 relocations in both habitats) and after separation (106 locations in cacao). Before the separation period, we registered 91 relocations for mothers and young. After the nurturing period, young were relocated in the riparian forest on 90 occasions and their mothers on 192 (Fig. 3). No young sloth used the cacao agroforest after separating from their mother. The habitat use for mother and young for each period is presented in Fig. 3 .

Tree species use: A total of 42 tree species were used by mother sloths and their young during the 14 months of this study. During the maternal care period, 22 tree species were used, with the most common being Cecropia obtusifolia (30.9\%), Coussapoa villosa $(25.6 \%)$, Nectandra salicifolia $(12.1 \%)$, Pterocarpus officinalis $(5.8 \%)$ and Samanea saman (5.4\%; Table 3). Following separation, 32 tree species were used by mothers with the most common being C. obtusifolia $(27.6 \%)$, C. villosa (18.5\%), N. salicifolia (10.3\%), S. saman (7.7), P. officinalis (6.8\%) and Ocotea sinnuata (4.3\%) (Table 4). However, their young used only 20 tree species, with the most common being $C$. villosa (18.4\%), S. saman (18.5\%) and N. salicifolia $(16.7 \%)$. This pattern of mothers using a greater diversity of trees was observed in all habitats following separation of mothers and young (Fig. 3). However, there was no significant difference in the use of tree species by mothers during the maternal care, post-maternal care toward young, or mothers following separation $\left(\chi^{2}=3.35, \mathrm{~d} . \mathrm{f}=2, \mathrm{p}>0.05\right)$.

Frequency of habitat use: The cacao agroforest was used only by mother sloths and never by their young following separation. The most frequent tree species used in this habitat were C.obtusifolia and S. saman. C.obtusifolia is a primary food species for $B$. variegatus but Samanea appeared to be used only for resting.

In the riparian forest, mother sloths used a total of 28 tree species (six species frequently) (Table 4). Four were used for food, including C. obtusifolia, C. villosa, N. salicifolia and $P$. officinalis. The young used 18 trees in this habitat with $N$. salicifolia and $S$. saman most commonly used. However, the young also rested and fed during the day in neighboring trees, primarily C. obtusifolia, C. villosa and O. sinnuata. However because our primary sampling periods were between 0700-1200 hours when sloths were resting, relatively few feeding observations were made.

In the pastures, 13 tree species were used by mother sloths, but of these, only C. obtusifolia and Pentaclethra macroloba were used as food. Use of tree species by young was limited to five species with $C$. villosa the most frequent (14 observations). Although frequency of tree use between young and the mother differed, no significant difference was found in use of tree species by vegetative cover $\left(\chi^{2}=4.66\right.$, d.f $=2, p=0.09$ ).

\section{DISCUSSION}

Home range and pattern of range use: During the November-March maternal care period, mother sloths frequented relatively small areas with their offspring, investing most of their time and energy in nurturing their young. Mothers explored new, but relatively small areas with their young, probably to provide a concentrated learning period (Soares \& Carneiro 2002). In captivity, three-toed sloth juveniles remain with their mothers between five and seven months after birth (Taube et al. 2001). In our study, a mother typically left her young after about 5 months and established a new home range at some distance from the young (Fig. 2). Upon separation, the young stayed exactly where its mother had left it for several days before beginning to explore its surroundings and forage alone. 
TABLE 3

Frequency of use of tree species by Bradypus variegatus mothers during and after the maternal care period

\begin{tabular}{|c|c|c|c|}
\hline List of tree species & $\begin{array}{l}\text { Maternal care toward young } \\
\qquad(\text { Nov-Apr) }\end{array}$ & $\begin{array}{l}\text { Post maternal care toward young } \\
\text { (May-Dec) }\end{array}$ & $\begin{array}{l}\text { Mother sloths } \\
\text { post-separation }\end{array}$ \\
\hline Acalipha sp. & & & 1 \\
\hline Artocarpus sp. & 1 & & 2 \\
\hline Bunchosia macrophylla & & 9 & \\
\hline Castilla elastica & 1 & & \\
\hline Cecropia insignis & & & 3 \\
\hline Cecropia obtusifolia** & 69 & 7 & 97 \\
\hline Cocus nucifera** & 8 & & 4 \\
\hline Cordia alliodora & 1 & 2 & 1 \\
\hline Coussapoa villosa & 57 & 21 & 65 \\
\hline Cupania cinerea & 1 & & 1 \\
\hline Erythrina poeppigiana & & 1 & 1 \\
\hline Ficus sp. & & 1 & \\
\hline Ficus werckleana & 1 & 2 & \\
\hline Genipa americana & & & 5 \\
\hline Goethalsia meiantha** & & & 2 \\
\hline Hampea appendiculata & & & 4 \\
\hline Hieronyma alchorneoides & & & 2 \\
\hline Hura crepitans & & & 1 \\
\hline Inga edulis & 4 & & \\
\hline Inga marginata & & & 1 \\
\hline Inga oerstediana & 4 & 7 & 12 \\
\hline Inga punctata & & 2 & \\
\hline Inga sapindoides & & 1 & \\
\hline Inga sp. & & 1 & 3 \\
\hline Leucaena leucocephala** & & & 6 \\
\hline Luehea seemannii & 6 & 2 & 3 \\
\hline Musa sp.** & & & 2 \\
\hline Nectandra salicifolia** & 27 & 18 & 36 \\
\hline Nephelium mutabile & & & 8 \\
\hline Unidentified & 2 & & 1 \\
\hline Ocotea sinnuata & 3 & 9 & 15 \\
\hline Pachira aquatica & & 1 & \\
\hline Pentaclethra macroloba & 5 & & 4 \\
\hline Piper aurantium & 1 & & \\
\hline Protium panamense & 1 & & 1 \\
\hline Pterocarpus officinalis & 13 & 1 & 24 \\
\hline Rollinia pittieri & 3 & 1 & 8 \\
\hline Samanea saman** & 12 & 20 & 27 \\
\hline Sloaenea sp. & 2 & & 8 \\
\hline Spondias mombin & & 1 & 2 \\
\hline Theobroma cacao** & 1 & & \\
\hline Virola koschnyi & & 1 & 1 \\
\hline Total & 235 & 108 & 351 \\
\hline
\end{tabular}

**Tree species used inside the cacao agroforest. 
TABLE 4

Frequency of species tree and habitat used by three-toed sloths (Bradypus variegatus) during and after the maternal care period

\begin{tabular}{|c|c|c|c|c|c|c|}
\hline \multirow{2}{*}{ List of tree species } & \multicolumn{2}{|c|}{ Cacao } & \multicolumn{2}{|c|}{ Riparian forest } & \multicolumn{2}{|c|}{ Pasture with isolated tree } \\
\hline & Mother & Young & Mother & Young & Mother & Young \\
\hline Acalipha sp. & & & 1 & & & \\
\hline Artocarpus sp. & & & 2 & & & \\
\hline Bunchosia macrophylla & & & & 9 & & \\
\hline Castilla elastica & & & 1 & & & \\
\hline Cecropia insignis & & & 3 & & & \\
\hline Cecropia obtusifolia** & 96 & & 48 & 7 & 72 & \\
\hline Cocus nucifera** & 8 & & & & & \\
\hline Cordia alliodora & & & 2 & 2 & & \\
\hline Coussapoa villosa & & & 40 & 7 & & 14 \\
\hline Cupania cinerea & & & 2 & & & \\
\hline No identification & & & 2 & & 1 & \\
\hline Erythrina poeppigiana & & & 1 & 1 & 1 & \\
\hline Genipa amaericana & & & 3 & & 2 & \\
\hline Goethalsia meiantha** & 2 & & & & & \\
\hline Hampea appendiculata & & & 4 & & & \\
\hline Hieronyma alchorneoides & & & & & 2 & \\
\hline Hura crepitans & & & 1 & & & \\
\hline Ficus sp. & & & & 1 & & \\
\hline Ficus werckleana & & & 1 & 2 & & \\
\hline \multicolumn{7}{|l|}{ Inga edulis } \\
\hline Inga marginata & & & 1 & & & \\
\hline Inga oerstediana & & & 14 & 6 & 2 & 1 \\
\hline Inga punctata & & & & 2 & & \\
\hline Inga sapindoides & & & & 2 & & \\
\hline Inga sp. & & & 1 & & 2 & 1 \\
\hline Leucaena leucocephala** & 6 & & & & & \\
\hline \multicolumn{7}{|l|}{ Licaria sarapiquensis } \\
\hline Luehea seemannii & & & 8 & 2 & & \\
\hline \multicolumn{7}{|l|}{ Musa sp.** } \\
\hline Nectandra salicifolia** & 8 & & 50 & 15 & 2 & 3 \\
\hline Nephelium mutabile & & & 8 & & & \\
\hline Ocotea sinnиata & & & 17 & 9 & 1 & \\
\hline Pachira aquatica & & & & & & 1 \\
\hline Pentaclethra macroloba & & & & & 9 & \\
\hline Piper aurantium & & & 1 & & & \\
\hline Protium panamense & & & 2 & & & \\
\hline Pterocarpus officinalis & & & 35 & 1 & 1 & \\
\hline Rollinia pittieri & & & 10 & 1 & 1 & \\
\hline Samanea saman** & 22 & & 12 & 20 & & \\
\hline Sloaenea sp. & & & 10 & & & \\
\hline Spondias mombin & & & & 1 & 2 & \\
\hline Theobroma cacao ${ }^{* *}$ & 1 & & & & & \\
\hline Virola koschnyi & & & 1 & 1 & & \\
\hline Total & 143 & 0 & 281 & 89 & 98 & 20 \\
\hline
\end{tabular}

***Tree species used inside the cacao agroforest. 
Mother sloths selected home ranges containing resources needed by young. Montgomery \& Sunquist (1978) suggested that offspring inherit the mother's food preferences during the nurturing period. The young also visited tree species we had not observed them in earlier, but with much less frequency than species they had visited with their mothers. Tree species used by young sloths were used for food, but especially for refuge and resting, e.g., Bunchosia macrophylla. Other tree species used by both mothers and young sloths during and after the maternal care period included $C$. villosa and N. salicifolia (Table 3). Young were often observed resting in trees adjacent to food sources. Juveniles used a smaller sub-set of those species used by their mothers (Table 4).

Why do mother sloths leave: Montgomery \& Sunquist (1978) and Taube et al. (2001) observed that wild mother sloths left their former home range to their young and established new home ranges. We observed that before separating, mother sloths remained from two to 10 meters from their young for several days, returning immediately if the young emitted a distress call, as noted previously by Montgomery \& Sunquist (1974). Williams (1966) believes that separation of mothers from young is a reproductive strategy because the female sloth was ready to mate again only after six months of reduced lactation. Taube et al. (2001) believe that mother sloths left their offspring in very favorable rearing conditions. Dispersal by the mother could benefit the young as it would be less vulnerable to predation or starvation then if the inexperienced offspring dispersed alone into an unknown area. After separation, offspring may share the same tree with other adult males and females for weeks. After a year separation, we observed one mother share the same tree with her offspring for three days, but she left shortly thereafter.

Sloth breeding season: Three-toed sloths are reported to have irregular breeding seasons depending on climatic conditions (Taube et al. 2001). In this study, three births occurred between November and December, which coincided with the end of the long rainy season. Births were also observed in April and May. Based on our data (Fig. 4) and a four to sixmonth gestation period (Beebe 1926), our study animals probably copulated between early May and the end of September. Based on field observations, we developed a calendar of mating and births (Fig. 4). We observed no reproductive behavior, only males in close proximity to females. Perhaps copulation occurs at night when we generally did not collect data. In captivity, Taube et al. (2001) found the gestation period for the three-toed sloth to be six months long; the interbirth interval was 10-12 months. Male and female three-toed sloths reached sexual maturity at three years of age (Montgomery 1983).

Tree species used: A total of 42 species were used by both mother and young sloths (Tables 3, 4). After the mothers separated from the young, adults began to utilize new tree species heretofore not used with their offspring. A few species seemed to be highly preferred by sloths, especially Cecropia, which forms an important seasonal component of the adult sloths diet (Goffart 1971, Vaughan et al. 2007) and occurs abundantly in gaps and secondary forest (Kricher 1997) and as shade trees within the cacao agroforest (Vaughan et al. 2007). A varied diet was reported in dry tropical forests (Ballesteros et al. 2009). In general, Bradypus consumed plants rich in nutrients and proteins,

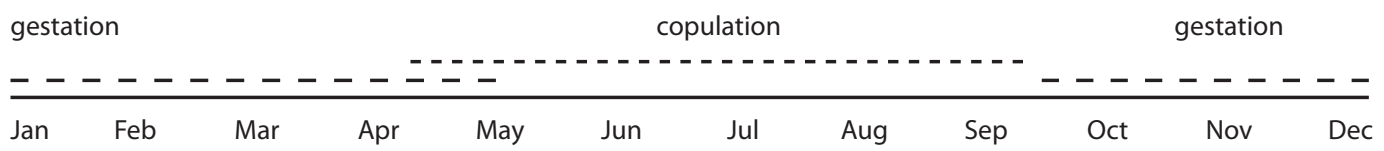

Fig. 4. Reproduction calendar for Bradypus variegatus. 
some of which also had toxic compounds such as phenols and lignin, which was difficult to digest (Belovsky \& Schmitz 1994, Coley \& Barone 1996).

Dispersal and cacao agroforest conservation: In most mammals, offspring are dependent on the mother for protection, transportation and learning. There is an initial nurturing period of absolute dependence followed by a brief period of separation with mothers close by. For sloths, the mothers separate and establish new home ranges, leaving the young to utilize the resources in the original small home range. Once the mother leaves, the juvenile uses food and refuge resources previously visited with its mother. Once independent, young sloths are frequently seen with other adult males and females, but not their mothers. These individuals may be members of extended families, but we do not have genetics data that could determine this. Undoubtedly, survival of the young depends on the presence of food and refuge. In time, juveniles increase their home range size. It is curious that the young observed in this study did not venture into the cacao agroforest but this habitat is more open that the riparian forest and fencerows frequented by juveniles. The separation of the mother and young demonstrates how Bradypus requires certain habitats in which to establish new home ranges after the nurturing period. In the study region, there is strong pressure to convert most forested areas into pineapple and banana plantations and pasture for cattle. The cacao agroforest with adjacent riparian forests and fencerows provides an important habitat type that links the smaller riparian and secondary forests.

\section{ACKNOWLEDGMENTS}

We thank Hugo Hermelink for access to his farm and for much logistical support. Funding for this research was provided by the U.S. Department of Agriculture, project \#58-12752-026, "Theobroma cacao: Biodiversity in Full and Partial Canopies", to the Milwaukee Public
Museum. Dagoba Chocolate and Idea Wild provided additional support for this research.

\section{RESUMEN}

La información sobre el comportamiento ecológico de los perezosos silvestre es muy escasa. Determinamos los ámbitos de acción y uso de recursos para hembras adultas de perezosos de tres dedos (Bradypus variegatus) y sus crías en una matriz agroforestal compuesta de cacao (Theobroma cacao), potreros, bosques ribereños y cercas vivas en Costa Rica. Los nacimientos de las crías se presentan frecuentemente de noviembre a diciembre y entre 5 a 7 meses las crías se vuelven independientes. Inicialmente las madres utilizan pocos árboles y van expandiendo el uso de recursos conforme las crías se van haciendo independientes de la madre. Las madres en los primeros meses guían a sus crías para seleccionar recursos y coberturas de bosque preferidos, y gradualmente se van separando de la cría hasta dejarlos en lo que fue su área núcleo. Ámbitos de acción de las crías (de hasta 7 meses o más de edad) varían entre 0.04-0.6ha, mientras que los ámbitos de acción de las madres varían 0.04-25.0ha. Durante el cuido maternal, 22 especies de árboles fueron utilizadas entre las más comunes se encuentran: Cecropia obtusifolia (30.9\%), Coussapoa villosa (25.6\%), Nectandra salicifolia (12.1\%), Pterocarpus officinalis (5.8\%) y Samanea saman (5.4\%). Los jóvenes utilizaron solo 20 especies entre las más comunes C. villosa (18.4\%), S. saman (18.5\%) y N. salicifolia $(16.7 \%)$. El sistema agroforestal del cacao fue únicamente utilizado por la madre y no por la cría después del periodo de separación. Sin embargo, en los bosques ribereños tanto la madre como la cría utilizaron árboles como recursos. Un total de 28 especies de árboles fueron utilizados por la madre incluyendo especies para su alimentación tales como: C. obtusifolia, C. villosa, N. salicifolia y P. officinalis. Los jóvenes solo utilizaron 18 especies de árboles como $N$. salicifolia and $S$. saman entre las más frecuentes; inclusive los árboles utilizados para descanso y alimentación durante el día fueron $C$. obtusifolia, $C$. villosa y $O$. sinnuata. Los sistemas agroforestales de cacao adyacentes a bosques ribereños y cercas vivas proveen un importante hábitat que une pequeños parches de bosques secundarios.

Palabras clave: B. variegatus, distribución espacial, ámbito de acción, cuido maternal, uso de recursos, sistema agroforestal de cacao, bosque ribereño, cercas vivas.

\section{REFERENCES}

Altmann, J. 1978. Infant independence in yellow baboons, p. 253-277. In G. Burghardt \& M. Bekoff (eds.). The development of behavior: comparative and evolutionary aspects. Garland, New York, USA. 
Ballesteros, C.J., C.K. Reyes \& C.J. Racero. 2009. Estructura poblacional y etología de Bradypus variegatus en fragmento de bosque seco tropical, Córdoba - Colombia. Rev. Mvz. Cordoba 14: 1812-1819.

Beebe, W. 1926. The three-toed sloth Bradypus cuculliger cuculliger. Wagler. Zoologica 7: 1-67.

Belovsky, G.E. \& O.J. Schmitz. 1994. Plant defenses and optimal foraging by mammalian herbivores. J. Mammal. 75: 816-832.

Britton, W.S. 1941. Form and function in the sloth. Q. Rev. Biol. 16: 190-207.

Chiarello, A.G. 1998. Activity budgets and ranging patterns of the Atlantic forest maned sloth Bradypus torquatus (Xenarthra: Bradypodidae). J. Zool. 246: 1-10.

Chiarello, A.G. 2004. A translocation experiment for the conservation of maned sloths, Bradypus torquatus (Xenarthra, Bradypodidae). Biol. Conservat. 118: 421-430.

Chiarello, A. 2008. Bradypus variegatus. In IUCN 2010. IUCN Red list of threatened species. Version 2010.4. (Consultado: 8 marzo 2010, www.iucnredlist.org).

CITES. 2010. Convention on International Trade in Endangered Species of Wild Fauna and FloraVersion. 2010. (Consultado: 14 octubre 2010, www.iucnredlist.org).

Clutton-Brock, T.H. 1991. The evolution of parental care. Princeton, New Jersey, USA.

Coley, P.D. \& J.A. Barone. 1996. Herbivory and plant defenses in tropical forests. Annu. Rev. Ecol. Systemat. 27: 305-335.

DeVore's, I. 1963. Mother-infant relations in free-ranging baboons, p. 305-335. In H. Rheingold (ed.). Maternal behavior in mammals. Wiley, New York, USA.

Eisenberg, J.F. \& E. Maliniak. 1985. Maintenance and reproduction of the two-toed sloths Choloepus didactylus in captivity, p. 327-331. In G.C. Montgomery (ed.). The evolution and ecology of armadillos, sloths and vermilinguas. Smithsonian Institution, Washington, D.C., USA.

Greene, H.W. 1989. Agonistic behavior by three-toed sloth, Bradypus variegatus. Biotropica 21: 369-372.

Goffart, M. 1971. Function and form in the sloth. Pergamon, Oxford, United Kingdom.
Holdridge, L. 1978. Life zone ecology. Centro Científico Tropical, San José, Costa Rica.

Kricher, J.C. 1997. A neotropical companion. Princeton, New Jersey, USA.

Meritt, D.A. \& G.F. Meritt. 1976. Sex ratios of Hoffmann's sloth, Choloepus hoffmanni Peters and three-toed sloth, Bradypus infuscatus Wagler, in Panama. Amer. Mild. Nat. 96: 472-473.

Meritt, D.A. 1985. The two-toed Hoffman's sloths, Choloepus hoffmanni Peters, p. 333-341. In G.C. Montgomery (ed.). The evolution and ecology of armadillos, sloths and vermilinguas. Smithsonian Institution, Washington, D.C., USA.

Montgomery, G.G. 1983. Bradypus variegatus (Perezoso de tres dedos, three-toed sloth), p. 453-456. In D.H. Janzen (ed.) Costa Rican natural history. University of Chicago, Chicago, USA.

Montgomery, G.G. \& M.E. Sunquist. 1974. Contact-distress calls of young sloths. J. Mammal. 55: 211-213.

Montgomery, G.G. \& M.E. Sunquist. 1978. Habitat selection and use by two-toed and three-toed sloths, p. 359. In G.G. Montgomery (ed.). The ecology of arboreal folivores. Smithsonian Institution,Washington, D.C., USA.

Mohr, C.O. 1947. Table of equivalent populations of North American small mammals. Amer. Midl. Nat. 37: 223-249.

Partridge, J. 1991. The two-toed sloth. International Zoo News 38: 23-28.

Rowell, T., N. Din \& A. Omar. 1968. The social development of baboons in their first three months. J. Zool. 155: 461-483.

Soares, C.A. \& R.S. Carneiro. 2002. Social behavior between mothers x young of sloths Bradypus variegatus Schinz, 1825 (Xenarthra: Bradypodidae). Braz. J. Biol. 62: 249-252.

Sunquist, M.E. \& G.G. Montgomery. 1973. Activity patterns and rates of movement of two-toed and threetoed sloths (Choloepus hoffmanni and Bradypus infuscatus). J. Mammal. 54: 946-954.

Taube, E., J. Keravec, J.C. Vié \& J.M. Duplantier. 2001. Reproductive biology and postnatal development in sloths, Bradypus and Choloepus: review with original data from the field (French Guiana) and from captivity. Mammal. Rev. 31: 173-188. 
Vaughan, C., O. Ramirez, G. Herrera \& R. Guries. 2007. Spatial ecology and conservation of two sloth species in a cacao landscape in Limón, Costa Rica. Biodivers. Conserv. 16: 2293-2310.

Veselovsky, Z. 1966. A contribution to the knowledge of the reproduction and growth of the two-toed sloth, Choloepus didactylus, at Prague Zoo. Int. Zoo. Yearbk. 6: 147-153.
Williams, G.C. 1966. Natural selection, the costs of reproduction and a rearrangement of Lack's principle. Am. Nat. 100: 687-690.

White, G.C. \& R.A. Garrott. 1990. Analysis of wildlife radio-tracking data. San Diego, California, USA.

Zar, J.H. 1984. Biostatistical analysis. Prentice-Hall, New Jersey, USA. 
